\title{
IIIICnghitung nilai emisivitas warna menggunakan miniatur ruang berbentuk silinder sebagai media pembelajaran fisika
}

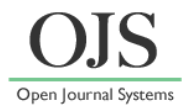

\author{
Susilawati $\mathbf{Z}^{1^{*}}$, Afrizal Mayub ${ }^{1}$, M. Farid ${ }^{2}$ \\ ${ }^{1}$ Pascasarjana Pendidikan IPA FKIP Universitas Bengkulu, Bengkulu \\ ${ }^{2}$ Jurusan Fisika FMIPA Universitas Bengkulu, Bengkulu \\ *Email: shoenoeo46@yahoo.com
}

\begin{abstract}
ABSTRAK
Penelitian ini bertujuan untuk mengetahui nilai emisivitas warna ungu (purple comet), hijau, biru, merah, hijau muda, biru muda, jingga, coklat muda, kuning, merah muda; serta mendeskripsikan peningkatan hasil belajar kognitif siswa dengan menggunakan model PBL pada konsep Perpindahan Kalor siswa kelas X-TKJ SMK Negeri 1 Bengkulu Tengah; dan menjelaskan perbedaan hasil belajar kognitif siswa pada kelompok tinggi, sedang dan rendah. Populasi dalam penelitian ini adalah seluruh siswa kelas X SMK Negeri 1 Bengkulu Tengah tahun pelajaran 2016/2017. Sampel diambil dengan teknik Purpose sampling, yaitu kelas X.TKJ (Teknik Komputer Jaringan) yang diajar dengan model pembelajaran Problem Based Learning (PBL). Penelitian ini adalah penelitian eksperimen semu dengan desain One Group pretest-posttest design. Hasil penelitian menunjukkan: Nilai emisivitas secara berurutan sebesar 0,$92 ; 0,83 ; 0,75 ; 0,62 ; 0,57 ; 0,54$; 0,$50 ; 0,40 ; 0,31 ; 0,24$; Terdapat peningkatan hasil belajar pada konsep Perpindahan Kalor siswa kelompok tinggi, sedang dan rendah dengan nilai $\mathrm{N}$-gain masing-masing sebesar 0,75 (tinggi), 0,52 (sedang), dan 0,44 (sedang); Terdapat perbedaan hasil belajar kognitif siswa pada kelompok tinggi, sedang dan rendah yang ditunjukkan oleh $\mathrm{F}_{\text {hitung }}>\mathrm{F}_{\text {tabel }}(4,04>3,35)$ pada taraf signifikansi $5 \%$.
\end{abstract}

Kata kunci: Emisivitas warna; miniatur ruang; silinder; media; pembelajaran fisika.

\section{PENDAHULUAN}

Emisivitas permukaan dapat didefinisikan sebagai kemampuan objek untuk memancarkan energi yang dimilikinya (Mallick dkk, 2012). Emisivitas berhubungan erat dengan proses perpindahan energi. Panas sebagai salah satu bentuk energi dapat berpindah dengan cara konduksi, konveksi dan radiasi. Perpindahan panas secara radiasi inilah yang berkaitan dengan konsep emisivitas. Penelitian-penelitian tentang pengaruh warna terhadap perpindahan panas telah banyak dilakukan sebelumnya. Uemoto (2010) mengatakan bahwa perubahan warna (polos, putih, kuning dan coklat) mempengaruhi perpindahan panas pada atap, dan warna coklat memiliki temperatur luar paling tinggi diantara warna-warna tersebut.

Permasalahannya sekarang adalah tingkat emisivitas warna yang diketahui saat ini hanya untuk warna hitam dan putih, dengan koefisien emisivitas 1 (satu) untuk warna hitam dan 0 (nol) untuk warna putih. Penelitian mengenai emisivitas warna selain hitam dan putih sangat tepat diterapkan pada mata pelajaran Fisika. Trianto (2007) mengemukakan bahwa fisika merupakan bagian dari Ilmu Pengetahuan Alam (IPA) yang mempelajari gejala-gejala dan kejadian alam melalui serangkaian proses yang dikenal dengan proses ilmiah yang dibangun atas dasar sikap ilmiah dan hasilnya berwujud produk ilmiah berupa konsep, hukum, teori yang berlaku universal.

Pembelajaran fisika pada hakikatnya terdiri atas tiga komponen yaitu proses, produk, dan sikap. Fisika sebagai proses, karena merupakan suatu rangkaian kegiatan yang terstruktur dan sistematis yang dilakukan untuk menemukan konsep, prinsip dan hukum tentang gejala alam. Fisika sebagai sebuah produk karena terdiri dari sekumpulan pengetahuan yang berupa fakta-fakta, konsepkonsep, prinsip dan hukum tentang gejala alam. Sedangkan fisika sebagai suatu sikap, 
karena diharapkan mampu mengembangkan karakter siswa (Anang, 2012).

Fakta di lapangan menunjukkan bahwa di Indonesia hasil pembelajaran sains khususnya fisika masih tergolong rendah. Berdasarkan hasil penelitian Organisation for Economic Co-operation and Development (OECD) dengan program PISA (2012), yaitu studi yang memfokuskan pada prestasi literasi, matematika dan sains menyatakan bahwa Indonesia menduduki peringkat 64 dari 65 negara partisipan. Himah, dkk (2015) mengemukakan hasil tersebut dapat disebabkan oleh beberapa faktor diantaranya kurang optimalnya pembelajaran di sekolah seperti penggunaan model pembelajaran yang kurang tepat atau kebiasaan pembelajaran yang masih menitikberatkan pada guru bukan pada aktivitas siswa. Sehingga motivasi siswa dalam mengikuti pembelajaran sangat kurang. Hal serupa ditemukan berdasarkan observasi di SMK Negeri 1 Bengkulu Tengah, sebagian besar siswa menganggap pelajaran fisika sebagai pelajaran yang sulit dan membosankan. Hal ini terjadi karena pelajaran fisika bersifat abstrak, empiris dan matematis sehingga minat dan motivasi siswa sangat kurang. Pelajaran Fisika juga lebih sering menampilkan persamaan matematis rumus daripada konsep fisikanya, sehingga siswa kesulitan mengaitkan materi dengan fenomena-fenomena alam yang terjadi dalam kehidupan. Hal ini berdampak pada rendahnya hasil belajar siswa. Dari hasil Ujian semester Ganjil Tahun Pelajaran 2016/2017 diketahui bahwa nilai rata-rata ujian semester Mata Pelajaran Fisika siswa kelas X sebesar 62, sementara Kriteria Ketuntasan Minimal (KKM) sebesar 70.

Ahli pembelajaran telah menyarankan penggunaan paradigma pembelajaran yang kontruktivistik untuk meningkatkan kualitas proses dan hasil belajar kegiatan belajar mengajar di kelas. Untuk itu, pembelajaran fisika tidak semata-mata mengajarkan konsepkonsep tetapi yang lebih penting adalah keterkaitan konsep-konsep tadi dengan kenyataan keseharian dalam kehidupan siswa (Trianto, 2007)

Perubahan paradigma pembelajaran tersebut menyebabkan terjadinya perubahan fokus pembelajaran dari yang belajar berpusat pada guru ke belajar berpusat pada siswa. Kondisi belajar yang dulunya siswa hanya menerima materi dari pengajar, mencatat, dan Website: https://ejournal.unib.ac.id/index.php/pendipa menghafalkannya harus diubah menjadi sharing pengetahuan, mencari, menemukan pengetahuan secara aktif sehingga terjadi peningkatan motivasi belajar dan membimbing siswa untuk senantiasa berpikir kritis dan kreatif. Tujuan tersebut dapat terwujud apabila pengajar dapat menggunakan pendekatan, strategi, model, atau metode pembelajaran inovatif. Salah satu model pembelajaran yang memiliki kriteria di atas adalah model Problem Based Learning (PBL) (Winarni, 2009).

Pembelajaran berbasis masalah (Problem based learning) atau yang biasa disingkat PBL merupakan salah satu model pembelajaran inovatif yang dapat memberikan kondisi belajar aktif kepada siswa. Model pembelajaran ini dilakukan dengan adanya pemberian rangsangan berupa masalahmasalah yang kemudian dilakukan pemecahan masalah oleh siswa yang diharapkan dapat menambah keterampilan siswa dalam pencapaian materi pembelajaran (Trianto, 2007).

Model Pembelajaran PBL memberikan ruang gerak berpikir yang bebas kepada siswa untuk mencari konsep dan menyelesaikan masalah yang terkait dengan materi yang diberikan oleh guru. Ilmu fisika pada dasarnya bertujuan agar siswa memahami konsepkonsep fisika yang ada dalam kehidupan. Memiliki pengetahuan mengenai proses-proses dan fenomena yang terjadi di alam sekitar merupakan salah satu kemampuan yang harus dimiliki oleh siswa. Pada akhirnya, kemampuan ini akan dapat digunakan untuk menerapkan berbagai konsep fisika dalam menjelaskan gejala alam dan menggunakan teknologi sederhana untuk memecahkan masalah yang terjadi dalam kehidupan seharihari (Depdiknas, 2006).

Berdasarkan latar belakang di atas, maka dilakukan penelitian berjudul "Menentukan Nilai Emisivitas Warna Menggunakan Miniatur Ruang Berbentuk Silinder pada Pembelajaran Fisika". Proses pembelajaran dilakukan dengan menggunakan model Pembelajaran Problem Based Learning (PBL) yang mungkin dapat menjadi salah satu alternatif untuk mengatasi permasalahan dan kesulitan belajar Fisika siswa.

Emisivitas setiap objek didasarkan pada hukum Kirchhoff, pada keseimbangan termal, tingkat emisi suatu benda atau permukaan setara dengan jumlah penyerapannya pada 
panjang gelombang yang sama. Penyerapan yang dimaksud adalah energi yang diserap oleh suatu benda yang didefinisikan berdasarkan panjang gelombang dan sudut datang tertentu, formula ini seperti pada Persamaan 1 (Lillesand et al., 2008). Selanjutnya dengan memperhitungkan konservasi energi, dimana total dari absorbsi, pantulan, dan transmisi $=1$, maka diperoleh Persamaan 2. Apabila yang diamati kebanyakan objek seperti benda-benda yang buram (opaque) dan tidak memancarkan radiasi, maka Persamaan 2 menjadi Persamaan 3.

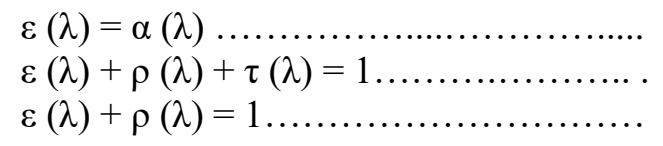

keterangan :

$\varepsilon=$ emisivitas

$\alpha=$ absorbsi

$\rho=$ pantulan

$\mathrm{T}=$ transmisi

$\lambda=$ panjang gelombang

Oleh karena itu, pancaran spektral objek dapat dihitung dari pantulan (untuk benda hitam). Dapat dikatakan, suatu benda/material dengan $\varepsilon$ yang tinggi akan menyerap sejumlah besar energi dan meradiasikan sejumlah besar energinya. Sedangkan benda/material dengan $\varepsilon$ yang rendah, akan menyerap dan meradiasikan energi yang lebih rendah (Sabin, 2007).

\section{METODE PENELITIAN}

Penelitian yang dilakukan bertujuan menentukan nilai emisivitas warna ungu (purple comet), hijau (going green), biru (true blue), merah (talk of the town), hijau muda (apple martini), biru muda (sky blue), jingga (orange torch), coklat muda (pastry puff), kuning (absolute yellow), dan merah muda (crystal pink). Penelitian dilakukan dilaksanakan di Laboratorium SMK Negeri 1 Bengkulu tengah pada tanggal 15-20 Maret 2017. Setelah data emisivitas diperoleh penelitian dilanjutkan di SMK Negeri 1 Bengkulu tengah pada tanggal $25-29$ April 2017.

Populasi dalam penelitian ini adalah seluruh siswa kelas $\mathrm{X}$ SMK Negeri 1 Bengkulu Tengah tahun pelajaran 2016/2017. Sampel diambil dengan teknik simple random Website: https://ejournal.unib.ac.id/index.php/pendipa sampling, yaitu kelas X.TKJ (Teknik Komputer Jaringan) yang diajar dengan model pembelajaran Problem Based Learning (PBL). Penelitian ini adalah penelitian eksperimen semu menggunakan desain one group pretestposttest design. Rancangan penelitian ditunjukkan pada Tabel 1 berikut ini:

Tabel 1. Desain penelitian

\begin{tabular}{cccc}
\hline \multirow{2}{*}{ Subjek } & Pretest & Perlakuan & Posttest \\
\cline { 2 - 4 } & $\mathrm{O}_{1}$ & $\mathrm{X}$ & $\mathrm{O}_{2}$ \\
\hline
\end{tabular}

Keterangan:

$\mathrm{O}_{1}=$ Pretest

$\mathrm{O}_{2}=$ Posttest

$\mathrm{X}=$ Perlakuan model Problem Based Learning

Variabel bebas dalam penelitian ini adalah model pembelajaran Problem Based Learning, sedangkan variabel terikatnya adalah hasil belajar fisika siswa. Instrumen penelitian terdiri atas perangkat pembelajaran (RPP dan LKS) dan instrumen pengumpulan data (soal pretest dan posttest sebanyak 10 soal). Sebelum digunakan, semua instrumen tersebut dilakukan uji validitas. Untuk RPP dan LKS hanya dilakukan uji validitas isi oleh satu orang dosen dan dua orang guru fisika. Sedangkan instrument tes kognitif dilakukan uji validitas isi dan reliabilitas (ICC) oleh satu orang dosen dan dua orang guru fisika (sebagai judgment experts). Setelah itu, soal tes kognitif diujikan di lapangan. Hasil yang diperoleh digunakan untuk menguji validitas, reliabilitas, tingkat kesukaran dan daya beda soal. Berdasarkan hasil uji tersebut diperoleh: (1) tes kognitif yang diterima 10 butir dengan realibilitas tinggi $\left(r_{11}=0,65\right)$, (2) sebanyak 5 butir soal tidak valid dan dibuang. Data penelitian ini berupa hasil belajar kognitif siswa. Data tersebut dianalisis dengan statistik deskriptif dan inferensial. Analisis deskriptif digunakan untuk mendeskripsikan hasil belajar kognitif siswa kelompok tinggi, sedang dan rendah. Sedangkan analsisis inferensial digunakan untk menguji hipotesis yang telah dirumuskan pada taraf signifikansi $5 \%$.

\section{HASIL DAN PEMBAHASAN}

Pengukuran nilai hambatan yang digunakan untuk menentukan nilai emisivitas menggunakan multimeter digital. Hasil 
perhitungan nilai emisivitas dari nilai hambatan yang diukur dengan multimeter digital dapat dilihat pada tabel 2 berikut ini:

Tabel 2. Emisivitas Rata-Rata ${ }^{1}$

\begin{tabular}{clc}
\hline No & \multicolumn{1}{c}{ Warna } & $\begin{array}{c}\text { Rata- } \\
\text { rata }\end{array}$ \\
\hline 1 & Ungu (purple comet) & 0.92 \\
\hline 2 & Hijau (going green) & 0.84 \\
\hline 3 & Biru (true blue) & 0.75 \\
\hline 4 & Merah (talk of the town) & 0.62 \\
\hline 5 & Hijau muda (apple & 0.57 \\
\hline 6 & martini) & 0.54 \\
\hline 7 & Biru muda(sky blue) & 0.50 \\
\hline 8 & Coklat muda (pastry puff) & 0.42 \\
\hline 9 & Kuning (absolute yellow) & 0.31 \\
\hline 10 & Merah muda (crystal pink) & 0.24 \\
\hline
\end{tabular}

Keterangan

${ }^{1}$ Pengukuran hambatan menggunakan multimeter digital

${ }^{2}$ Pengukuran hambatan menggunakan multimeter analog

Data hasil penelitian ini didapat urutan warna berdasarkan nilai emisivitas terbesar sampai yang terkecil. Urutan warna yang didapat yaitu : ungu (purple comet), hijau (going green), biru (true blue), merah (talk of the town), hijau muda (apple martini), biru muda (sky blue), jingga (orange torch), coklat muda (pastry puff), kuning (absolute yellow), dan yang terakhir merah muda (crystal pink). Urutan tersebut terlihat berdasarkan tingkat gelap dan terang suatu warna. Semakin gelap suatu warna maka semakin besar nilai emisivitasnya, sebaliknya semakin terang suatu warna maka semakin kecil nilai emisivitasnya. Besar kecilnya nilai emisivitas menunjukkan kemampuan suatu benda/zat menyerap energi panas dari lingkungannya (Lillesand et al., 2008).

Hasil penelitian ini tidak bertentangan dengan penelitian-penelitian yang telah dilakukan sebelumnya. Satwiko (dalam Yohana et, al: 2011) yang menyatakan nilai emisivitas atau absorbsi panas warna gelap lebih besar dibandingkan dengan warna terang sehingga warna gelap cenderung menangkap atau menyimpan panas sedangkan warna terang cenderung memiliki sifat memantulkan panas.
Hasil tersebut didukung oleh Ilminnafik (2015) dalam penelitiannya yang berjudul variasi bahan dan warna atap bangunan untuk menurunkan temperatur ruangan akibat pemanasan global menyatakanbahwa warna gelap (merah) cenderung menyerap panas lebih besar dibandingkan warna lebih cerah (abu-abu).

Nilai emisivitas pada setiap warna ini jika dibandingkan dengan nilai emisivitas pada literatur (Table of Total Emissivity Omegascope) memiliki perbedaan yang sangat jauh. Perbedaan nilai emisivitas ini dapat terjadi karena warna yang digunakan dalam penelitian tidak sama dengan warna pada literatur. Bahan yang digunakan juga berbeda, pada literatur sebagian besar menggunakan warna bahan logam sedangkan peneliti memakai warna cat tembok. Perbedaan alat yang digunakan juga sangat berpengaruh. Pada literatur, alat yang digunakan adalah omegascope atau Infrared Pyrometers, sedangkan peneliti menggunakan multimeter untuk mencari perbandingan nilai hambatan warna untuk mendapatkan nilai emisivitasnya. Penggunaan alat multimeter sangat cocok untuk pembelajaran, karena alat ini mudah didapat dan mudah untuk digunakan. Secara umum, laboratorium sekolah memiliki multimeter, sehingga guru fisika dapat mengadopsi penelitian ini untuk memberikan variasi pembelajaran fisika.

Pengetahuan mengenai nilai emisivitas warna sangat penting dalam kehidupan. Pemilihan warna yang tepat untuk bangunan juga sangat berpengaruh terhadap penyerapan energi radiasi cahaya lampu pada setiap bangunan. Hal ini tentu saja dapat dijadikan sebagai salah satu solusi penghematan listrik pada skala bangunan, yang paling mudah diterapkan pada skala rumah tinggal dengan mempertimbangkan konfigurasi arsitekturalnya, susunan material, dimensi hingga pewarnaan dinding bangunan perlu diperhatikan.

Upaya penghematan energi listrik dengan mempertimbangkan pemilihan warna cat bangunan tentunya sejalan dengan program pemerintah. Peraturan Pemerintah Nomor 79 Tahun 2014 tentang Kebijakan Energi Nasional Pasal 6 menyatakan bahwa semua pihak harus memanfaatkan energi secara efisien di semua sektor. Pemilihan warna cat yang sesuai untuk bangunan dapat 
menekan jumlah konsumsi energi listrik, yang dapat diartikan sebagai salah satu upaya pemanfaatan energi secara efisien.

Semakin terang warna cat yang digunakan terbukti semakin kecil konsumsi energi cahaya lampu pada suatu ruangan. Yohana dan Novariawan (2011) mengemukakan penelitian mengenai panas yang tersimpan di dalam ruangan akan lebih besar dengan dinding bagian luar menggunakan cat warna gelap dibandingkan dengan rumah yang dinding bagian luarnya menggunakan cat warna terang. Nilai ratarata panas yang tersimpan pada rumah menggunakan exhaust fan dengan tanpa cat 10,34 Watt, warna cat putih 6,93 watt, warna cat abu-abu 9,56 wattdan warna cat kuning 7,63 watt. Sedangkan panas yang tersimpan pada rumah tanpa menggunakan exhaust fan (secara alami) dengan tanpa cat sebesar 11,79 watt, cat putih 7,00 watt, cat abu-abu 10,83 watt dan warna cat kuning 8,46 watt. Setelah data emisivitas diperoleh penelitian dilanjutkan dalam proses pembelajaran di SMK Negeri 1 Bengkulu Tengah pada tanggal 25 - 29 April 2017. Hasil penelitian memperoleh data-data sebagai berikut:

\section{Rata-rata Pretest dan Postest}

Hasil pretest dan Postest dapat dilihat pada gambar 1 berikut ini:

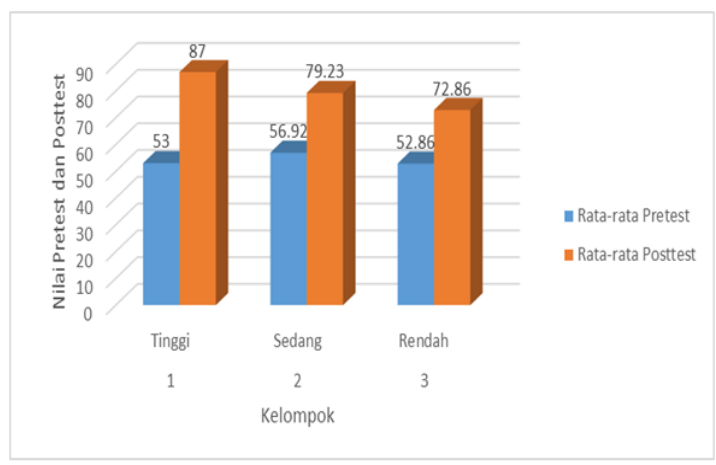

Gambar 1. Grafik nilai rata-rata pretest dan posttest

Dari gambar terlihat masing-masing kelompok mengalami peningkatan hasil belajar kognitif. Kelompok tinggi mengalami kenaikan rata-rata nilai sebesar 34; kelompok sedang sebesar 22,31; kelompok rendah sebesar 20,0.

\section{Simpangan Baku}

Website: https://ejournal.unib.ac.id/index.php/pendipa
Simpangan baku nilai posttest yang diperoleh dari penelitian sebesar sebesar 11,60 untuk kelompok tinggi, kelompok sedang sebesar 8,62 dan kelompok rendah sebesar 11,10. Hal ini mengindikasikan bahwa kelompok tinggi memiliki sebaran nilai yang lebih tinggi daripada kelompok lainnya.

\section{Perhitungan Gain}

Tabel 6 menunjukkan bahwa kelompok tinggi memiliki nilai $\mathrm{N}$-gain lebih tinggi dari kelompok lainnya sebesar 0,75 dalam katagori tinggi. Kelompok sedang memiliki nilai $\mathrm{N}$-gain sebesar 0,52 dalam katagori sedang. Kelompok rendah memiliki nilai $\mathrm{N}$-gain paling rendah sebesar 0,44 dalam katagori sedang. Hal ini berarti bahwa kelompok tinggi memiliki peningkatan nilai yang lebih tinggi dari kelompok lainnya.

\section{Analisis Inferensial}

Analisis inferensial dalam penelitian ini menggunakan uji ANAVA. Ringkasan perhitungan Anava dapat dilihat pada Tabel 3 berikut ini:

Tabel 3. Ringkasan Perhitungan Anava tentang penerapan model PBL

\begin{tabular}{|c|c|c|c|c|c|c|}
\hline $\begin{array}{c}\text { Sum } \\
\text { ber } \\
\text { Vari } \\
\text { ans }\end{array}$ & $\begin{array}{c}\text { Ju } \\
\text { ml } \\
\text { ah } \\
\mathbf{K u} \\
\text { adr } \\
\text { at } \\
(\mathbf{J} \\
\mathbf{K}) \\
\end{array}$ & $\begin{array}{c}\text { De } \\
\text { raj } \\
\text { at } \\
\text { be } \\
\text { bas }\end{array}$ & $\begin{array}{c}\text { Ku } \\
\text { adr } \\
\text { at } \\
\text { Re } \\
\text { rat } \\
\text { a } \\
\text { (K } \\
\text { R) } \\
\end{array}$ & $\begin{array}{c}F_{\text {hit }} \\
\text { ung }\end{array}$ & $\begin{array}{l}\text { Ta } \\
\text { raf } \\
\text { Sig } \\
\text { nifi } \\
\text { ka } \\
\text { nsi }\end{array}$ & $\begin{array}{l}\text { Kepu } \\
\text { tusan }\end{array}$ \\
\hline $\begin{array}{c}\text { Anta } \\
\mathrm{r} \\
\text { kelo } \\
\text { mpo } \\
\mathrm{k}\end{array}$ & $\begin{array}{c}851 \\
, 50\end{array}$ & 2 & $\begin{array}{l}425 \\
, 75\end{array}$ & & $\begin{array}{c}\alpha= \\
0,0 \\
5\end{array}$ & $\begin{array}{c}\mathrm{F}_{\text {hitung }} \\
> \\
\mathrm{F}_{\text {tabel }} \\
4,04\end{array}$ \\
\hline $\begin{array}{c}\text { Dala } \\
\mathrm{m} \\
\text { kelo } \\
\text { mpo } \\
\mathrm{k}\end{array}$ & $\begin{array}{c}2.8 \\
45, \\
16\end{array}$ & 27 & $\begin{array}{l}105 \\
, 38\end{array}$ & $\begin{array}{c}4,0 \\
4\end{array}$ & $\begin{array}{c}\mathrm{F}_{\text {tab }} \\
\text { el }= \\
3,3 \\
5\end{array}$ & $\begin{array}{c}> \\
3,35 \\
\text { Jadi } \\
\mathrm{H}_{\mathrm{a}} \\
\text { diteri } \\
\text { ma }\end{array}$ \\
\hline Total & - & 29 & - & & & \\
\hline
\end{tabular}

Dari perhitungan N-gain diperoleh kesimpulan bahwa masing-masing kelompok mengalami peningkatan hasil belajar. Untuk mengetahui apakah terdapat perbedaan kenaikan hasil belajar siswa kelompok tinggi, sedang dan rendah maka dilakukan uji Analisis Varian (Anava). Uji ANAVA menunjukkan $F_{\text {hitung }}>F_{\text {tabel }}(4,04>3,35)$ pada taraf signifikansi $5 \%$, sehingga $\mathrm{H}_{\mathrm{a}}$ diterima dan $\mathrm{H}_{0}$ ditolak. Kesimpulan dari perhitungan anava adalah terdapat perbedaan hasil belajar 
kognitif siswa pada kelompok tinggi, sedang dan rendah dengan menggunakan model PBL.

Peningkatan hasil belajar kognitif siswa tidak terlepas dari beberapa faktor pendukung, baik yang bersifat internal maupun yang bersifat eksternal. Faktor internal yang turut serta berperan dalam meningkatkan pemahaman serta hasil belajar kognitif fisika siswa yaitu berupa kemampuan-kemampuan yang terdapat dalam diri siswa, salah satunya adalah kemampuan untuk menguasai aturanaturan atau langkah-langkah yang diperlukan dalam proses sains itu sendiri. Sedangkan faktor eksternal yang turut mendukung peningkatan kemampuan pemahaman serta hasil belajar kognitif fisika siswa pada siswa salah satunya adalah dengan penerapan model pembelajaran PBL dalam kegiatan pembelajaran (Trianto, 2007).

Penerapan model pembelajaran PBL sangat efektif digunakan dalam proses pembelajaran di kelas karena kegiatan pembelajaran diawali dengan pemberian struktur masalah riil kepada siswa yang berkaitan dengan konsep Fisika yang akan dipelajari. Setiap siswa terlibat secara mental maupun fisik untuk memecahkan masalah yang diberikan guru, sehingga siswa menjadi terbiasa bersikap teliti, mandiri, tekun, jujur, kreatif, dan menghormati pendapat orang lain (Himah, 2015).

Hasil penelitian pembelajaran yang diperoleh sangat sesuai dengan penelitian sebelumnya yang pernah dilakukan oleh Abdurrozak, dkk (2016) dalam penelitiannya mengenai Pengaruh Model Problem Based Learning terhadap Kemampuan Berpikir Kreatif Siswa. Kesimpulan yang diperoleh bahwa terdapat peningkatan kemampuan berpikir kreatif siswa dengan menggunakan model PBL, 2) terdapat peningkatan hasil belajar siswa dengan menggunakan model PBL, dan 3) kemampuan berpikir kreatif siswa dengan menggunakan model PBL lebih baik daripada menggunakan model konvensional.

\section{KESIMPULAN}

Berdasarkan hasil penelitian dan pembahasan dapat ditarik kesimpulan bahwa : 1) Nilai emisivitas warna ungu (purple comet) adalah 0,92; emisivitas warna hijau (going Website: https://ejournal.unib.ac.id/index.php/pendipa green) adalah 0,83; emisivitas warna biru (true blue) adalah 0,75; emisivitas warna merah (talk of the town) adalah 0,62; emisivitas warna hijau muda (apple martini) adalah 0,57; emisivitas warna biru muda (sky blue) adalah 0,54; emisivitas warna jingga (orange torch) adalah 0,50; emisivitas warna coklat muda (pastry puff) adalah 0,40; emisivitas warna kuning (absolute yellow) adalah 0,31; dan emisivitas warna merah muda (crystal pink) adalah $0,24,2)$ Terdapat peningkatan hasil belajar pada konsep Perpindahan Kalor siswa kelas X-TKJ SMK Negeri 1 Bengkulu Tengah kelompok tinggi, sedang dan rendah.

\section{DAFTAR PUSTAKA}

Abdurrozak, R., Asep. K. J dan Isrok. A. 2016. Pengaruh Model Problem Based Learning Terhadap Kemampuan Berpikir Kreatif Siswa. Jurnal Pena Ilmiah: Vol. 1, No, 1 (2016). Diakses 18 Mei 2017

Depdiknas. 2006. Kurikulum Tingkat Satuan Pendidikan. Jakarta : Depdiknas.

Himah, E. F., Singgih. B dan Trapsilo. P. 2015. Penerapan Model Problem Based Learning (PBL) Disertai Metode Pictorial Riddle Dalam Pembelajaran Fisika di SMA. Jurnal Pembelajaran Fisika, Vol.4 No.3, Desember 2015, hal 261 - 267. Diakses 7 Juni 2017.

Ilminnafik, N., Digdo L.S., Hary. S., Ade. A. M. M dan Erfani. M. 2015. Variasi bahan dan warna atap bangunanuntuk Menurunkan Temperatur Ruangan akibat Pemanasan Global. Seminar Nasional Tahunan Teknik Mesin XIV (SNTTM XIV). Banjarmasin, 7-8 Oktober 2015. Diakses 29 Juni 2016

Lillesand, T. M., Kiefer. R. W dan Chipman. H. W. 2008. Remote Sensing and Image Interpretation. New York : Sixth ed.John Willey \& Son

Mallick, J., Singh. C. K., Shashtri. S., Rahman. A dan Mukherjee. S. 2012. Land surface emissivity retrieval based on moisture index from LANDSAT TM satellite data over heterogeneous surfaces of Delhi City. International Journal of Applied Earth Observation and Geoinformation, 19, pp. 384-358. Diakses 9 September 2016

Suardani, N. 2014. Pengaruh Model Pembelajaran Berbasis Masalah 
terhadap Kemampuan Pemecahan Masalah dan Keterampilan Proses Sains Siswa. e-Journal Program Pascasarjana Universitas Pendidikan Ganesha Program Studi IPA. Vol.4. Diakses 9 Juni 2016

Sudewi, N.L. 2014. Studi Komparasi Penggunaan Model Pembelajaran Problem Based Learning (PBL) dan Kooperatif Tipe Group Investigation (GI) terhadap Hasil Belajar Berdasarkan Taksonomi Bloom. Journal Program Pascasarjana Universitas Pendidikan Ganesha Program Studi IPA. Vol 4. Diakses 9 Juni 2016

Sugiyono. 2010. Metode Penelitian. Bandung: Alfabeta

Trianto. 2007. Model-model Pembelajaran Inovatif Berorientasi Konstruktivistik : Konsep, Landasan, Teoritis-Praktis dan Implementasinya. Jakarta: Prestasi Pustaka

Uemoto, K. L., Neide. M. N., Vanderley dan John. S. 2010. Estimating Thermal Performance of Cool Colored Paints. http://www.elsevier.com/locate/enbuil d. Diakses 9 Juni 2016

Winarni, E.W. 2009. Mengajar IPA secara Bermakna. Bengkulu: UNIB PRESS

Yohana, E dan Bayu N. 2011. Perbandingan Stack Effect pada Rumah secara Konveksi Paksa dan Konveksi Alami Ketika Kondisi 